\title{
Pengaruh Konflik Pekerjaan-Keluarga Kelelahan Emosional dan Stres Kerja Terhadap Kinerja
}

\author{
Kharis Septina Liftyawan, Faizal Susilo Hadi, Tri Siwi Agustina \\ Universitas Airlangga \\ Email: kharis.septina.liftyawan-2017@ feb.unair.ac.id, \\ faizal.susilo.hadi-2017@feb.unair.ac.id, siwi@feb.unair.ac.id \\ Diterima: November 2019; Dipublikasikan Januari 2020
}

\begin{abstract}
ABSTRAK
Kinerja karyawan merupakan hal yang penting yang dapat mempengaruhi jalannya kinerja perusahaan. Kinerja karyawan dapat dipengaruhi oleh beberapa faktor, konflik pekerjaan-keluarga dapat menjadi faktor penting yang dapat menurunkan kinerja karyawan. Konflik pekerjaan-keluarga yang tinggi akan mengakibatkan kelelahan emosional dan stres kerja pada karyawan. Populasi dalam penelitian ini adalah karyawan PT. Morich Indo Fashion II. Pengambilan sampel menggunakan teknik pengambilan sampel propotionate random dan perhitungan jumlah sampel menggunakan rumus slovin yang diketahui sebesar 96 karyawan PT Morich Indo Fashion. Metode pengumpulan data menggunakan kuesioner dan wawancara. Metode Analisis data menggunakan analisis deskriptif, analisis regresi, dan analisis jalur (path analysis). Hasil penelitian menunjukkan bahwa terdapat pengaruh yang positif signifikan konflik pekerjaan-keluarga pada kelelahan emosional. Hasil juga menunjukkan bahwa terdapat pengaruh yang positif signifikan konflik pekerjaan-keluarga pada stres kerja. Sedangkan konflik pekerjaankeluarga menunjukkan hasil yang negatif namun tidak signifikan terhadap kinerja. Kelelahan emosional dan stres kerja tidak terbukti memediasi hubungan konflik pekerjaan-keluarga pada kinerja karyawan, yang ditunjukkan dengan nilai koefisien hubungan langsung lebih besar dari pada hubungan tidak langsung.Kesimpulan dari penelitian ini adalah konflik antara pekerjaan-keluarga sangat berperan penting untuk mengukur kinerja karyawan.
\end{abstract}

Kata Kunci : work-family conflict; kelelahan emosional; stress kerja; kinerja

\begin{abstract}
Employes performance is important that can possibly influence an company. Employes performance itself can be affected by several factors. Work-family conflict can be an important factor that can degrade the performance of employe. A work-family conflict leads to high emotional fatigue on the employe. The population of this study was the employes of PT Morich Indo Fashion. The samples were selected by using proportionate random. The samples were calculated by applying slovin formula consisting of 96 employes of PT. Morich Indo Fashion. The methods of data analysis were descriptive analysis, regression analysis and path analysis. The results of the study showed that there was a significant positive influence of work-family conflict on emotional exhaustion. The results also showed that there was a significant positive effect of Works-family conflict on the job stress. While the work-family conflict showed negative results but there were no significant effects on the performance. Emotional exhaustion and job stres was rejected that it mediated between the relationship of work family conflict and lecturer's performance as it was indicated by demonstrated a direct relationship with coefficient greater Ethan inderect relationship. The conclusion of this study is work-family conflict is very important to measure the performance of employee.
\end{abstract}

Keywords : work-family conflict; emotional exhaustion; job stress; job performance 


\section{PENDAHULUAN}

Seiring meningkatnya dunia usaha selaras dengan peningkatan kondisi perekonomian di Indonesia membuat semua sektor usaha bersaing ketat. Perusahaan sebagai organisasi bisnis dituntut untuk beradaptasi dengan perubahan yang terjadi pada lingkungan bisnis. Semakin bertambahnya perusahaan-perusahaan kompetitor juga menjadi tantangan untuk terus meningkatkan kualitas organisasi dan menciptakan manajemen yang efektif. Tantangan lain yang dialami perusahaan adalah semakin kompleksnya permintaan konsumen untuk memenuhi kebutuhan sehari-hari. Dengan banyaknya tantangan yang harus dihadapi, perusahaan harus meningkatkan kinerja perusahaan (Griffin \& Moorhead, 2014).

Kinerja sebuah perusahaan sangat dipengaruhi oleh sumber daya manusia (Paparang \& Rumokoy, 2015:110). Menurut Astianto (2014:5-7) Semakin baik kinerja karyawan maka kinerja perusahaan akan meningkat. Perusahaan selalu berusaha menyediakan sarana dan prasarana untuk menunjang kinerja karyawan, tetapi sarana dan prasarana yang memadai harus diimbangi dengan kualitas sumber daya manusia yang memiliki kompetensi. Jika karyawan tidak memiliki kompetensi yang sesuai dengan bidang pekerjaannya maka perusahaan akan sulit bersaing dan berkembang. Hal ini menunjukkan bahwa perusahaan tidak terlepas dari peran sumber daya manusia yang perlu untuk banyak diperhatikan. Oleh karena itu karyawan mendapatkan banyak tuntutan untuk meningkatkan kompetensi dan kinerjanya (Setyono dkk., 2007:71).

Perusahaan merekrut sumber daya manusia untuk dipekerjakan dan menjalankan perusahaan untuk tetap bertahan di dunia usaha. Perusahaan memberikan kompensasi dan pelatihan pada karyawan dengan tujuan karyawan memberikan kontribusi dalam pencapaian tujuan organisasi yang dapat di tunjukkan dalam bentuk kinerja (Wisantyo \& Madiistriyatno, 2015:67). Hal ini menandakan bahwa perusahaan memberi tanggung jawab pada karyawannya sesuai dengan kemampuan atau keahlian dalam melaksanakan pekerjaan. Kinerja merupakan kemampuan karyawan untuk melaksanakan pekerjaan dengan baik atau tidak. Jika karyawan melaksanakan pekerjaannya dengan baik berarti karyawan merasa puas dengan pekerjaannya. Sebaliknya, jika karyawan memiliki kinerja yang buruk mereka tidak puas dengan pekerjaannya (Sukmawati dkk, 2013:552). Buruknya kinerja karyawan dapat disebabkan oleh berbagai hal, salah satu yang menjadi penyebab dikarenakan adanya konflik pekerjaan-keluarga (Christine dkk., 2010:129).

Menurut Warokka \& Febrilia (2015:2) konflik pekerjaan-keluarga terjadi jika seseorang merasa tidak mampu mengatur dan menyeimbangkan tanggung jawabnya untuk memenuhi kedua peran yang dijalankan. Tuntutan yang dialami karyawan dalam menjalankan pekerjaan mengakibatkan berkurangnya peran dan tanggung jawab pada keluarga (Karatepe, 2013:618). Misalnya karyawan sering melaksanakan tugas kantor di luar kota membuat waktu untuk bertemu dengan keluarga berkurang sehingga istri atau suami merasa tidak diperhatikan yang mengakibatkan pertengkaran pasangan. Sebaliknya tuntutan keluarga yang mengganggu pekerjaan seperti karyawan yang mengalami pertengkaran suami istri membuat karyawan tidak fokus untuk mengerjakan pekerjaan yang ada di kantor sehingga tugas yang diberikan tidak terselesaikan dengan baik. Dampak dari konflik pada seseorang bervariasi di antaranya adalah menciptakan kecemasan, frustasi, ketegangan atau rasa bermusuhan (Robbins \& Judge, 2008:370). Dampak dari konflik bergantung pada di mana konflik berasal serta gangguan antara pekerjaan dan keluarga secara alami saling mempengaruhi antara keduanya (Rajak, 2013:135). 
Penelitian Netemeyer et al.(1996) menyatakan hubungan antara pekerjaan dan keluarga bersifat dua arah. Pertama, Konflik Pekerjaan ke Keluarga sebagai sebuah bentuk interrole conflict dimana secara keseluruhan adanya tuntutan waktu tertentu serta ketegangan yang ditimbulkan karena gangguan dari pekerjaan terhadap tanggung jawab didalam keluarga. Hal ini biasanya terjadi pada saat seseorang berusaha memenuhi tuntutan peran dalam pekerjaan dan usaha tersebut dipengaruhi oleh kemampuan orang yang bersangkutan untuk memenuhi tuntutan keluarganya atau sebaliknya, dimana pemenuhan tuntutan peran dalam memenuhi tuntutan dengan tekanan yang berasal dari beban kerja yang berlebihan dan waktu (contohnya seperti pekerjaan yang harus diselesaikan terburu-buru dan deadline). Sedangkan tuntutan keluarga berhubungan dengan waktu yang dibutuhkan untuk menangani tugas-tugas rumah tangga. Kedua, Konflik Keluarga ke Pekerjaan sebagai sebuah bentuk interrole conflict dimana secara keseluruhan adanya tuntutan waktu tertentu serta ketegangan yang ditimbulkan karena gangguan dari keluarga terhadap tanggung jawab didalam pekerjaan.

Konflik pekerjaan-keluarga sering menjadi permasalahan yang dihadapi karyawan dan mengganggu produktivitas karyawan untuk menjalankan tugas-tugasnya (Ranihusna \& Wulansari, 2015:215). Banyaknya tuntutan pada pekerjaan dan tanggung jawab dalam keluarga menjalankan peran sebagai seorang ayah atau suami dan ibu atau istri membuat karyawan sering mengalami stres kerja (Tziner \& Sharoni, 2014:41) atau bahkan mengalami kondisi yang lebih buruk yaitu kelelahan emosional (Jensen, 2014:505) Setiap orang pasti mengalami stres, baik di dalam organisasi maupun di luar organisasi. Stres mengakibatkan dampak yang negatif pada keadaan psikologis dan biologis karyawan (Griffin \& Moorhead, 2014:179). Stres kerja dapat membantu untuk meningkatkan kinerja karyawan atau malah merusak kinerja karyawan (Handoko, 2011:202) Dari pernyataan tersebut dapat disimpulkan bahwa jika tantangan-tantangan kerja merasa tidak ada, kinerja karyawan tidak meningkat, dan prestasi kerja cenderung rendah apabila tidak ada stres. Meningkatnya stres dapat meningkatkan kinerja, karena stres membantu karyawan untuk mengerahkan seluruh sumber daya dalam menyelesaikan pekerjaannya. Apabila stres kerja sudah mencapai puncak, maka stres kerja cenderung membuat kinerja karyawan menurun. Stres akan mengganggu pekerjaan sehingga tidak ada pekerjaan yang terselesaikan.

Konflik pekerjaan-keluarga yang berkelanjutan dapat mengakibatkan kelelahan emosional (emotional exhaustion). Menurut penelitian Poernomo \& Wulansari (2015:198), konflik pekerjaan-keluarga dapat mengakibatkan kelelahan emosional yang dapat berdampak pada kinerja karyawan. Dengan banyaknya tuntutan dari pekerjaan yang dirasakan karyawan, mulai dari banyaknya tugas yang harus dikerjakan, karyawan dituntut untuk mengembangkan kompetensi dengan tujuan untuk meningkatkan sumber daya manusia pada perusahaan dan waktu yang tersita untuk menjalankan pekerjaannya. Selain itu, karyawan juga dituntut untuk menjalankan peran seorang istri dan ibu dalam keluarga. Kelelahan emosional terjadi jika perasaan tertekan dan kelelahan yang dirasakan karyawan terus menerus berlanjut yang berakibat terkurasnya sumber daya emosional dan energi.

Penelitian ini dilakukan pada karyawan PT. Morich Indo Fashion untuk mengetahui apakah ada pengaruh antara konflik pekerjaan-keluarga, kelelahan emosional, stres kerja, dan kinerja. Perusahaan ini dipilih karena dari hasil wawancara sebagian karyawan PT Morich Indo Fashion menyatakan bahwa mereka mengalami konflik pekerjaan-keluarga. Dari hasil wawancara dapat disimpulkan karyawan PT. Morich Indo Fashion mengalami tuntutan peran sebagai istri, ibu, dan anak yang harus menjalankan tugas dan tanggung jawabnya di dalam keluarga. Hal tersebut membuat 
karyawan merasa terbebani dan menurunkan semangat kerja yang dapat berdampak pada kinerja karyawan. Selain tekanan dari keluarga, karyawan juga merasakan tekanan dari perusahaan yang membuat beban dan tanggung jawab karyawan bertambah. Bertambahnya target yang harus diselesaikan bertambah pula tugas dan pekerjaan yang harus diselesaikan. Untuk mencapai target tersebut karyawan diberi jam tambahan atau lembur sehingga membuat berkurangnya waktu bersama keluarga. Hal tersebut membuat karyawan merasakan kesalahan dan kelalaian untuk bertanggung jawab atas kewajiban yang harus dilakukan dalam keluarga. Berbedanya tanggung jawab yang harus dihadapi karyawan antara keluarga dan pekerjaan membuat karyawan mengalami konflik pekerjaan-keluarga.

Data produksi PT Morich Indo Fashion memperlihatkan adanya peningkatan produksi perusahaan pada bulan Januari 2016 memproduksi 3521 pcs sampai dengan juli 2016 meningkat menjadi 6135 pcs. Berdasarkan hal tersebut dapat diketahui bahwa jumlah produksi setiap bulan bertambah dengan rata-rata jumlah karyawan hampir sama. Meningkatnya produksi PT Morich Indo Fashion membuat jumlah pekerjaan karyawan bertambah sehingga karyawan harus lebih lama di tempat kerja dan menghabiskan banyak tenaga dan fikiran pada tempat kerja. Hal tersebut membuat waktu karyawan dengan keluarga semakin berkurang sehingga dapat memicu terjadinya konflik pekerjaan-keluarga.

Permasalah tambahan yang dihadapi PT. Morich Indo Fashion adalah meningkatnya jumlah karyawan yang bolos kerja pada tahun 2016. Bulan Januari 2016 jumlah karyawan resensi karyawan yang tidak hadir selama satu bulan sebanyak 902, sedangkan pada bulan juli meningkat drastis menjadi 9275. Berdasarkan hal tersebut dapat diketahui jumlah karyawan yang tidak hadir tanpa keterangan setiap bulan mengalami peningkatan. Peningkatan paling signifikan terjadi pada bulan juli dengan jumlah karyawan yang tidak hadir sejumlah 9275. Jika dirata-rata karyawan yang tidak hadir tanpa keterangan pada bulan juli adalah 4,344 yang artinya setiap karyawan perempuan PT Morich Indo Fashion tidak hadir tanpa keterangan dalam sebulan sebanyak empat kali absen pada hari kerja. Tingginya jumlah karyawan yang tidak hadir tanpa keterangan dapat mengganggu produktivitas PT Morich Indo Fashion.

\section{TINJAUAN PUSTAKA}

\section{Konflik Keluarga-Pekerjaan (Work-Family Conflict)}

Greenhaus \& Beutell (1985) mendefinisikan konflik pekerjaan-keluarga merupakan bentuk konflik antara peran yang diakibatkan oleh tuntutan peran di tempat kerja dan keluarga saling bertentangan dalam beberapa hal. Konflik antara pekerjaankeluarga diidentifikasikan sebagai bentrokan antara peran yang berhubungan dengan pekerjaan yang dapat mengurangi tingkat kinerja karyawan (Greenhaus, Collins, \& Shaw, 2003) Sedangkan Netemeyer et al. (1996) berpendapat konflik pekerjaan-keluarga merupakan bentuk konflik yang terjadi ketika tuntutan pekerjaan dapat mengganggu tanggung jawab terhadap keluarga, meliputi: tuntutan; waktu; dan ketegangan yang berasal dari pekerjaan. Konflik pekerjaan-keluarga (konflik peran ganda) didefinisikan ketidakjelasan atau konflik antar peran pekerjaan dan peran keluarga yang menyebabkan stres peran keluarga atau stres peran pekerjaan (Grandey \& Cropanzano, 1999). Menurut (Christine dkk., 2010) konflik pekerjaan-keluarga terjadi saat partisipasi dalam peran pekerjaan dan peran keluarga saling tidak cocok antara satu dengan lainnya. Adanya partisipasi peran pekerjaan pada keluarga yang membuat peran keluarga menjadi terganggu. Sebaliknya, adanya partisipasi peran keluarga pada pekerjaan membuat peran 
pekerjaan terganggu. Hal tersebut membuat tekanan peran dari pekerjaan dan keluarga yang saling bertentangan dalam beberapa hal.

\section{Kelelahan Emosional}

Kelelahan emosional adalah kelelahan yang terjadi ketika karyawan dihadapkan pada tuntutan pekerjaan yang berlebihan dan tidak dapat mengelola antara peran dan konflik yang terjadi pada pekerjaan dan keluarga (Karatepe, 2013:616). Kelelahan emosional adalah tahapan awal dari gejala kelelahan mental/ burnout (Maslach \& Jackson, 1981:3). Contohnya, beban kerja yang terlalu berat yang membuat pekerja menghabiskan waktunya di kantor secara terus menerus dan mengurangi waktu bersama keluarga sehingga pekerja mengalami kelelahan emosional yang berlebihan. Dari pengertian tersebut dapat disimpulkan bahwa kelelahan emosional adalah kelelahan emosi yang disebabkan menipisnya sumber daya, energi dan waktu yang diakibatkan konflik peran yang berlebihan.

\section{Stres Kerja}

Stres yang dialami oleh karyawan merupakan masalah bagi perusahaan yang perlu diperhatikan guna meningkatkan kualitas sumber daya manusia. Definisi stres kerja menurut Dewi, dkk. (2014:) yaitu, ketegangan yang dialami karyawan karena adanya ketidakseimbangan antara tuntutan pekerjaan dengan kemampuan karyawan untuk menyelesaikan pekerjaannya. Menurut Handoko (2011:200) stres adalah suatu kondisi ketegangan yang mempengaruhi emosi, proses berpikir dan kondisi seseorang. Tingkat stres yang terlalu tinggi dapat mengancam kemampuan seseorang untuk menghadapi lingkungan. Sebagai hasilnya, pada diri karyawan berkembang berbagai gejala stres yang dapat mengganggu pelaksanaan kerja mereka. Stres dalam kerja secara umum dikatakan bahwa jika seseorang dihadapkan pada pekerjaan yang melampaui kemampuan individu tersebut, individu tersebut mengalami stres kerja. Seseorang dikategorikan mengalami stres kerja apabila stres itu dialami dan melibatkan juga pihak organisasi perusahaan tempat individu bekerja (Anies, 2014:194). Mendelson (1990) mendefinisikan stres akibat kerja merupakan suatu ketidakmampuan pekerja untuk menghadapi tuntutan tugas dengan akibat suatu ketidaknyamanan dalam kerja. Menurut Europian Commission (1999) stres akibat kerja adalah suatu bentuk emosional, kognitif, perilaku dan reaksi fisiologis terhadap aspek-aspek pekerjaan, organisasi kerja, lingkungan kerja yang bersifat merugikan (Tarwaka, 2013: 376). Stres kerja adalah perasaan menekan atau tertekan yang dialami karyawan dalam menghadapi pekerjaan. Stres kerja ini tampak dari Simptom antara lain emosi tidak stabil, sulit tidur, perasaan tidak senang, merokok yang berlebihan, suka menyendiri, tidak bisa tenang, cemas, tegang, tekanan darah meningkat, gugup, dan mengalami gangguan pencernaan (Mangkunegara, 2000:157).

\section{Kinerja}

Istilah kinerja berasal dari kata Job Performance atau Actual Performance (kinerja atau prestasi nyata) yang berkaitan dengan segala aktivitas dalam suatu organisasi kerja. Pengertian kinerja oleh Mangkunegara (2000: 67) adalah hasil kerja secara kualitas, kuantitas, efesiensi dan efektif yang dicapai oleh seorang karyawan dalam melaksanakan tugas sesuai dengan tanggung jawabnya yang diberikan kepadanya. Dessler (2005:73) kinerja adalah keseluruhan pelaksanaan aktivitas fisik dan psikologi yang dilakukan oleh manusia untuk mencapai tujuan tertentu atau mengandung suatu maksud tertentu, terutama yang berhubungan dengan kelangsungan hidupnya. Panton et al. (2006:1486) mengungkapkan bahwa komponen kinerja meliputi kemampuan 
individual, perluasan usaha, dan dukungan organisasional. Kemampuan individual mencakup minat, bakat, faktor kepribadian. Usaha meliputi motivasi, etika kerja, kehadiran, dan rancangan tugas. Sedangkan dukungan organisasional terdiri atas pelatihan dan pengembangan, peralatan dan teknologi, manajemen, serta rekan kerja.

\section{METODE PENELITIAN}

Identifikasi variabel dimaksudkan untuk mengetahui variabel apa saja yang digunakan dalam penelitian (Ferdinand, 2006). Didalam penelitian ini variabel yang akan diteliti ialah work-family conflict (WFC), kelelahan emosional stress kerja dan kinerja karyawan. Metode yang digunakan pada penelitian ini adalah dengan pendekatan kuantitatif. Penelitian kuantitatif lebih menekankan kepada logika berpikir yang lebih positivistik dengan mengacu fakta sosial yang dilihat dari realitas objektif (Moleong, 2005). Populasi dalam penelitian ini adalah seluruh karyawan perempuan pada PT Morich Indo Fashion. Jumlah sampel yang diambil pada penelitian ini sejumlah 96 karyawan perempuan. Teknik pengambilan sampel pada penelitian ini menggunakan teknik propotionate stratified random sampling. Metode pengumpulan data menggunakan kuesioner sejumlah 38 item pertanyaan. Varibel yang digunakan pada penelitian ini adalah variabel independen konflik pekerjaan-keluarga sedangkan variabel dependen adalah kinerja karyawan dan variabel mediasi adalah kelelahan emosional dan stres kerja.

\section{Uji Validitas dan Uji Reliabilitas}

Uji instrumen penelitian dilakukan untuk menguji kecukupan dan kelayakan data yang digunakan dalam penelitian. Kualitas data bertujuan untuk mengetahui validitas dan reliabilitas instrumen sebab berpengaruh pada kualitas data (Ghozali, 2011). Uji validitas digunakan untuk mengukur sah atau valid tidaknya suatu kuesioner. Suatu kuesioner dikatakan valid jika pertanyaan pada kuesioner mampu untuk mengungkapkan sesuatu yang akan diukur oleh kuesioner tersebut. Pengujian validitas dapat dilakukan dengan bantuan program SPSS. Pengujian suatu data dapat dikatakan valid apabila nilai Sig hitung $<$ Sig $\alpha 5 \%(0,05)$. Uji Reliabilitas adalah alat untuk mengukur suatu kuesioner yang merupakan indikator dari variabel atau konstruk. Suatu kuesioner dikatakan reliabel jika jawaban seseorang terhadap pernyataan adalah konsisten atau stabil dari waktu ke waktu (Ghozali, 2011). Uji reliabilitas dapat dilakukan dengan bantuan program SPSS. Pengujian suatu data dapat dikatakan reliabel apabila nilai Cronbach's Alpha > 0,6.

\section{Uji Signifikansi Parameter Individual}

Penelitian ini menggunakan uji signifikansi parameter individual (uji t). Ghozali (2011:98) menyatakan uji statistik t pada dasarnya menunjukkan seberapa jauh pengaruh atau variabel penjelas/independen secara individual dalam menerangkan variasi variabel dependen.

\section{Analisis Jalur (Path Analysis)}

Ghozali (2011) mengemukakan bahwa untuk menguji variabel mediasi digunakan metode analisis jalur (path analysis) analisis jalur merupakan perluasan dari analisis regresi linear berganda, atau analisis jalur adalah penggunaan analisis regresi untuk menaksir hubungan kausalitas antar variabel (model kausal) yang telah ditetapkan sebelumnya berdasarkan teori. Analisis jalur tidak dapat menentukan hubungan sebab 
akibat dan juga tidak dapat digunakan sebagai substitusi bagi peneliti untuk melihat hubungan kausalitas antar variabel.

Untuk mengukur ada tidaknya pengaruh mediasi atau intervening menggunakan perbandingan koefisien jalur. Koefisien jalur sendiri menurut Sarwono, (2007) adalah koefisien regresi standar yang menunjukkan pengaruh langsung suatu variabel bebas dan variabel tergantung dalam suatu model. Koefisien jalur dihitung dengan membuat dua persamaan regresi yang menunjukkan hubungan yang dihipotesiskan (Ghozali, 2011).

\section{HASIL DAN PEMBAHASAN}

\section{Identitas Responden Berdasarkan Usia}

Berdasarkan hasil perhitungan dapat dilihat persentase tertinggi merupakan responden berusia 18-24 tahun sebesar 39,6\%, sedangkan persentase terendah adalah responden berusia 39-46 tahun sebesar $11,5 \%$. Hal tersebut dapat dijelaskan sebagian besar karyawan yang bekerja pada PT Morich Indo Fashion II berada pada usia produktif bekerja yaitu pada usia 18-24 tahun.

\section{Identitas Responden Berdasarkan Status Perkawinan}

Identifikasi responden berdasarkan status perkawinan karyawan di PT. Morich Indo Fashion II diketahui bahwa jumlah karyawan yang belum kawin lebih banyak dari pada dengan karyawan yang sudah kawin dengan jumlah karyawan yang belum kawin adalah 58,3\% hal tersebut menunjukkan bahwa karyawan PT Morich Indo Fashion II mayoritas karyawannya belum kawin.

\section{Identitas Responden Berdasarkan Pendidikan Terakhir}

Identifikasi responden berdasarkan pendidikan terakhir karyawan di PT. Morich Indo Fashion II dapat diketahui bahwa persentase tertinggi merupakan responden yang telah menempuh pendidikan terakhir SMA sederajat sebesar 57,3\%, sedangkan persentase terendah adalah responden yang menempuh pendidikan SD sebesar 7,3\%. Hal tersebut menunjukkan bahwa sebagian besar karyawan yang bekerja pada PT Morich Indo Fashion II lulusan pendidikan SMA.

\section{Identitas Responden Berdasarkan Masa Kerja}

Identifikasi responden berdasarkan masa kerja karyawan di PT. Morich Indo Fashion II dapat dilihat bahwa persentase tertinggi merupakan responden yang bekerja selama 1-3 tahun sebesar 53,1\%, sedangkan persentase terendah adalah responden yang bekerja selama 10-12 tahun sebesar 3,1\%. Hal tersebut dapat dijelaskan sebagian besar karyawan yang bekerja pada PT Morich Indo Fashion II adalah karyawan yang telah bekerja selama 1-3 tahun.

\section{Hasil Uji Validitas}

Uji validitas digunakan untuk menguji sejauh mana ketepatan alat pengukur dapat mengungkapkan konsep gejala/kejadian yang diukur. Pengujian validitas dilakukan dengan bantuan program SPSS. Pengujian suatu data dapat dikatakan valid apabila nilai Sig hitung $<$ Sig $\alpha 5 \%(0,05)$.Pengujian validitas selengkapnya dapat dilihat pada tabel 5 . 
Tabel 1. Hasil Pengujian Validitas

\begin{tabular}{|c|c|c|c|c|}
\hline \multirow{2}{*}{ No } & Variabel/Indikator & \multirow{2}{*}{$\begin{array}{l}\text { Nilai sig alpha } \\
\text { hitung }\end{array}$} & \multirow{2}{*}{$\begin{array}{l}\text { Nilai sig alpha } \\
\text { ditentukan }\end{array}$} & \multirow{2}{*}{ Keterangan } \\
\hline & Konflik Keluarga-Pekerjaan & & & \\
\hline 1 & X.1 & 0,001 & 0,05 & Valid \\
\hline 2 & X.2 & 0,000 & 0,05 & Valid \\
\hline 3 & X.3 & 0,000 & 0,05 & Valid \\
\hline 4 & X.4 & 0,000 & 0,05 & Valid \\
\hline \multirow[t]{2}{*}{5} & X.5 & 0,000 & 0,05 & Valid \\
\hline & Kelelahan Emosional & & & \\
\hline 6 & $\mathrm{Z} 1.1$ & 0,000 & 0,05 & Valid \\
\hline 7 & $\mathrm{Z} 1.2$ & 0,006 & 0,05 & Valid \\
\hline 8 & $\mathrm{Z} 1.3$ & 0,002 & 0,05 & Valid \\
\hline 9 & $\mathrm{Z} 1.4$ & 0,000 & 0,05 & Valid \\
\hline 10 & $\mathrm{Z} 1.5$ & 0,000 & 0,05 & Valid \\
\hline 11 & Z1.6 & 0,005 & 0,05 & Valid \\
\hline 12 & $\mathrm{Z} 1.7$ & 0,010 & 0,05 & Valid \\
\hline \multirow[t]{2}{*}{13} & $\mathrm{Z} 1.8$ & 0,002 & 0,05 & Valid \\
\hline & Stres Kerja & & & \\
\hline 14 & $\mathrm{Z} 2.1$ & 0,000 & 0,05 & Valid \\
\hline 15 & $\mathrm{Z} 2.2$ & 0,000 & 0,05 & Valid \\
\hline 16 & $\mathrm{Z} 2.3$ & 0,000 & 0,05 & Valid \\
\hline 17 & Z2.4 & 0,000 & 0,05 & Valid \\
\hline 18 & $\mathrm{Z} 2.5$ & 0,000 & 0,05 & Valid \\
\hline 19 & $\mathrm{Z} 2.6$ & 0,000 & 0,05 & Valid \\
\hline 20 & Z2.7 & 0,000 & 0,05 & Valid \\
\hline 21 & $\mathrm{Z} 2.8$ & 0,000 & 0,05 & Valid \\
\hline \multirow[t]{2}{*}{22} & Z2.9 & 0,000 & 0,05 & Valid \\
\hline & Kinerja Karyawan & & & \\
\hline 23 & Y.1 & 0,002 & 0,05 & Valid \\
\hline 24 & Y.2 & 0,003 & 0,05 & Valid \\
\hline 25 & Y.3 & 0,003 & 0,05 & Valid \\
\hline 26 & Y.4 & 0,989 & 0,05 & Tidak Valid \\
\hline 27 & Y.5 & 0,037 & 0,05 & Valid \\
\hline 28 & Y.6 & 0,000 & 0,05 & Valid \\
\hline 29 & Y.7 & 0,007 & 0,05 & Valid \\
\hline 30 & Y.8 & 0,18 & 0,05 & Valid \\
\hline 31 & Y.9 & 0,009 & 0,05 & Valid \\
\hline 32 & Y.10 & 0,000 & 0,05 & Valid \\
\hline 33 & Y.11 & 0,000 & 0,05 & Valid \\
\hline 34 & Y.12 & 0,000 & 0,05 & Valid \\
\hline
\end{tabular}

Sumber: Data Diolah, (2016)

Tabel 1 menunjukkan bahwa korelasi antara masing-masing indikator terhadap total skor konstruk dari setiap variabel menunjukkan hasil yang valid, kecuali pada 1 item pertanyaan yang tidak valid yaitu nomor 26 , hal tersebut dikarenakan memiliki nilai sig hitung > sig alpha (0.05) sehingga 1 item pertanyaan tersebut dihilangkan karena sudah terwakili dengan pertanyaan yang lain. Sedangkan item pertanyaan yang lain dinyatakan valid dimana nilai sig hitung < sig alpha (0.05).

\section{Hasil Uji Reliabilitas}

Uji reliabilitas dilakukan dengan bantuan program SPSS. Pengujian suatu data dapat dikatakan reliabel apabila nilai Cronbach's Alpha >0,6. 
Tabel 2 : Hasil Pengujian Reliabilitas

\begin{tabular}{lllll}
\hline No & Variabel & $\begin{array}{l}\text { Alpha } \\
\text { hitung }\end{array}$ & Standart alpha & Keterangan \\
\hline 1 & WFC (X) & 0,715 & 0,70 & Reliabel \\
\hline 2 & Kelelahan Emosional (Z1) & 0,743 & 0,70 & Reliabel \\
\hline 3 & Stres kerja (Z2) & 0,923 & 0,70 & Reliabel \\
\hline 4 & Kinerja Karyawan (Y) & 0,715 & 0,70 & Reliabel
\end{tabular}

Sumber: Data Diolah, (2016)

Berdasarkan data yang ada dalam tabel diatas, dapat dilihat bahwa dari 3 variabel yang ada memiliki nilai koefisien reliabilitas > 0.70 maka dapat disimpulkan bahwa pada variabel Konflik pekerjaan-keluarga, Kelelahan Emosional, Stres Kerja dan Kinerja Karyawan adalah reliabel.

\section{Hasil Uji Signifikansi Parameter Individual}

Pengujian hipotesis dalam penelitian ini menggunakan uji statistik $\mathrm{t}$ untuk menunjukkan seberapa jauh pengaruh variabel independen secara individual dalam menerangkan variasi variabel dependen. Hipotesis dikatakan diterima sig hitung $<$ sig disyaratkan $(5 \%)$.

Tabel 3. Pengaruh Konflik Pekerjaan-Keluarga pada Kelelahan Emosional

\begin{tabular}{|c|c|c|c|c|c|c|}
\hline \multirow[t]{2}{*}{ Model } & & \multicolumn{2}{|c|}{ Unstandardized Coefficients } & \multirow{2}{*}{$\begin{array}{l}\text { Standardize } \\
\text { d } \\
\text { Coefficients } \\
\text { Beta }\end{array}$} & \multirow[t]{2}{*}{$\mathbf{t}$} & \multirow[t]{2}{*}{ Sig. } \\
\hline & & B & Std. Error & & & \\
\hline \multirow{2}{*}{1} & (Constant) & 10.252 & 1.937 & .459 & 5.293 & .000 \\
\hline & X & .756 & .151 & & 5.004 & .000 \\
\hline
\end{tabular}

Sumber: Data Diolah, (2016)

Konflik pekerjaan-keluarga berpengaruh langsung terhadap kelelahan emosional pada karyawan PT. Morich Indo Fashion. Hasil pengolahan data secara statistik konflik pekerjaan-keluarga memiliki nilai t hitung sebesar 5,004 dengan tingkat signifikansi $0,000<0,05$ sehingga dapat diartikan bahwa konflik pekerjaan-keluarga memiliki pengaruh pada kelelahan emosional.

Tabel 4. Pengaruh Konflik Pekerjaan-Keluarga pada Stres Kerja

\begin{tabular}{|c|c|c|c|c|c|c|}
\hline \multirow[t]{2}{*}{ Model } & & \multicolumn{2}{|c|}{ Unstandardized Coefficients } & \multirow{2}{*}{$\begin{array}{l}\text { Standardize } \\
\text { d } \\
\text { Coefficients } \\
\text { Beta }\end{array}$} & \multirow[t]{2}{*}{$\mathbf{t}$} & \multirow[t]{2}{*}{ Sig. } \\
\hline & & B & Std. Error & & & \\
\hline \multirow{2}{*}{1} & (Constant) & 14.419 & 2.114 & .419 & 6.822 & .000 \\
\hline & $X$ & .739 & .165 & & 4.480 & .000 \\
\hline
\end{tabular}

Sumber: Data Diolah, (2016) 
Konflik pekerjaan-keluarga mempunyai pengaruh langsung pada stres kerja pada karyawan PT Morich Indo Fashion. Berdasarkan hasil uji statistik yang telah dilakukan, diperoleh sig. hitung sebesar 0,000 lebih kecil dibandingkan sig. yang diisyaratkan yaitu 0,05 . Sehingga dapat diketahui bahwa konflik pekerjaan-keluarga mempunyai pengaruh positif dan signifikan terhadap stres kerja.

Tabel 5. Pengaruh Konflik pekerjaan-Keluarga, Kelelahan Emosional, dan Stres Kerja Pada Kinerja

\begin{tabular}{|c|c|c|c|c|c|c|}
\hline \multirow[t]{2}{*}{ Model } & & \multicolumn{2}{|c|}{ Unstandardized Coefficients } & \multirow{2}{*}{$\begin{array}{l}\text { Standardize } \\
\text { d } \\
\text { Coefficients } \\
\text { Beta } \\
\end{array}$} & \multirow[t]{2}{*}{$\mathbf{t}$} & \multirow[t]{2}{*}{ Sig. } \\
\hline & & B & Std. Error & & & \\
\hline \multirow{4}{*}{1} & (Constant) & 47.411 & 3.111 & & 15.242 & .000 \\
\hline & X & .214 & .224 & .112 & .955 & .342 \\
\hline & Y1 & -.009 & .145 & -.007 & -.060 & .953 \\
\hline & Y2 & -.261 & .133 & -.241 & -1.965 & .052 \\
\hline
\end{tabular}

Sumber: Data Diolah, (2016)

Konflik pekerjaan-keluarga tidak mempunyai pengaruh langsung pada kinerja pada karyawan PT. Morich Indo Fashion. Berdasarkan hasil uji statistik yang telah dilakukan diperoleh sig. hitung 0,342>0,05 sehingga konflik antara pekerja-keluarga tidak memiliki pengaruh pada kinerja. Kelelahan emosional tidak berpengaruh langsung pada karyawan PT. Morich Indo Fashion. Berdasarkan hasil uji statistik yang telah dilakukan, diperoleh sig hitung sebesar 0,953>0,05. Sehingga dapat diketahui hipotesis tidak diterima karena nilai sig hitung lebih besar dari sig yang sudah ditentukan yaitu $5 \%$.

\section{Hasil Analisis Jalur (Path Analysis)}

Analisis jalur (path analysis) digunakan untuk mengukur hubungan kausalitas antar variabel yang telah ditetapkan sebelumnya. Adapun variabel kausalitas yang diuji dalam penelitian ini adalah konflik pekerjaan keluarga terhadap kinerja dan apakah hubungan konflik pekerjaan-keluarga terhadap kinerja dimediasi oleh kelelahan emosional dan stres kerja. Untuk mengukur ada tidaknya pengaruh mediasi digunakan perbandingan koefisien jalur. Koefisien jalur dihitung dengan membuat dua persamaan yaitu persamaan regresi model 1, model 2 dan model 3 yang menunjukkan hubungan yang dihipotesiskan.

\section{Pembahasan}

\section{Pengaruh Konflik Pekerjaan-Keluarga Terhadap Kelelahan Emosional}

Karyawan lebih banyak mengalami kurangnya kebersamaan dengan keluarga dan konflik antara komitmen dan tanggung jawab pada keluarga. Dari kedua indikator tersebut menjadi alasan terbesar karyawan mengalami konflik pekerjaan-keluarga yang berdampak pada kondisi mental menurun sehingga membuat karyawan merasa lelah pada jam akhir kerja. Kurangnya kebersamaan antara karyawan dan keluarga membuat karyawan merasakan ketidak nyamanan saat menjalankan aktivitas di tempat kerja. Selain itu, kurangnya kedekatan karyawan dengan keluarga membuat karyawan merasa terbebani sehingga membuat karyawan mengalami penurunan kondisi mental yang 
berdampak pada kelelahan emosional. Kelelahan emosional pada karyawan dapat dilihat pada akhir jam kerja dimana karyawan merasakan kelelahan fisik dan psikis karena harus memikirkan tanggung jawab pada keluarga dan tanggung jawab pada tempat kerja Hal tersebut dapat dilihat dari nilai indeks indikator variabel kelelahan emosional yang tertinggi yaitu merasa lelah pada akhir kerja yang memiliki nilai indeks sebesar $59 \%$. Hasil penelitian adanya pengaruh antara konflik pekerjaan-keluarga pada kelelahan emosional didukung oleh penelitian Jensen (2014), Karatepe (2013), Karatepe \& Tekinkus (2006), Richter et al., (2015) dan Rubioa et. al. (2015).

\section{Pengaruh Konflik Pekerjaan-Keluarga Terhadap Stres Kerja}

Karyawan yang mengalami konflik pekerjaan-keluarga dapat meningkatkan stres kerja. Selain itu kurangnya kebersamaan keluarga dan adanya konflik antara komitmen dengan tanggung jawab pada keluarga menjadi alasan terbesar karyawan mengalami konflik pekerjaan-keluarga. Kurangnya kebersamaan dalam keluarga membuat hubungan antara karyawan dengan keluarga menjadi kurang harmonis sehingga membuat karyawan mengalami stres kerja. Selain itu stres kerja yang dirasakan karyawan juga dipengaruhi oleh banyaknya kuantitas pekerjaan yang diberikan. Kurangnya harmonis hubungan antara karyawan dengan keluarga dan banyaknya tugas yang diberikan pada karyawan membuat kondisi psikis menjadi memburuk sehingga karyawan merasakan stres kerja. Hasil penelitian ini juga didukung oleh penelitian Boles et.al. (1997), Wallace (2005), Prel \& Peter (2015), Rajak (2013), dan Tziner \& Sharoni (2014).

\section{Pengaruh Konflik Pekerjaan-Keluarga Terhadap Kinerja}

Karyawan yang mengalami konflik pekerjaan-keluarga tidak mempengaruhi aktivitas di tempat kerja untuk menjalankan tugas dan mencapai target yang sudah ditentukan. Meskipun karyawan mengalami konflik pekerjaan-keluarga tetapi tidak mempengaruhi aktivitas untuk menjalankan tugas yang sudah diberikan sehingga kinerja karyawan tetap tinggi. Karyawan menghasilkan kerja sesuai dengan standar yang ditetapkan oleh perusahaan. Meskipun mengalami konflik pekerjaan-keluarga, karyawan PT Morich Indo Fashion tetap profesional dalam menjalankan tugas seperti selalu hadir tepat waktu, jarang atau tidak pernah membolos saat bekerja, selalu memenuhi target yang ditentukan, menjaga kualitas pekerjaannya, dan mampu bekerja sama dengan karyawan lain meskipun suasana hati yang tidak tenang. Banyaknya tekanan yang dihadapi karyawan tertutama tekanan dalam keluarga juga tidak membuat karyawan merasa terlalu terbebani sehingga karyawan mampu menjalankan tugas-tugas yang diberikan dengan baik. Hasil penelitian ini juga didukung oleh penelitian Mete et.al. (2014), Anggriana et.al. (2014), Poernomo \& Wulansari (2015), dan Karatepe \& Tekinkus (2006). Hasil penelitian ini menunjukkan stres kerja tidak berpengaruh pada kinerja karyawan PT. Morich Indo Fashion. Hal tersebut dapat diketahui dari hasil uji statistik yang memperlihatkan nilai sig hitung sebesar 0,052>0,05 sehingga hipotesis ditolak, artinya karyawan yang mengalami stres kerja tidak mengurangi kuantitas dan kualitas pekerjaan yang dihasilkan.

\section{Pengaruh Kelelahan Emosional Terhadap Kinerja}

Karyawan yang mengalami kelelahan emosional tidak mempengaruhi kualitas dan kuantitas pekerjaan yang dihasilkan. Kemudian kelelahan yang dirasakan karyawan tidak tinggi. Selain itu karyawan tidak mengalami tekanan kerja yang tinggi dari atasan maupun dari teman bekerja. Karyawan juga tidak merasa frustrasi yang berlebihan saat bekerja. Kenyamanan lingkungan kerja seperti adanya musik yang di mainkan saat 
bekerja dan suhu udara yang sesuai membuat karyawan merasa nyaman. Selain itu juga dapat meminimalisir frustrasi yang dirasakan karyawan sehingga tetap menjalankan tugas dengan kuantitas dan kualitas yang ditargetkan. Hasil penelitian ini juga didukung oleh penelitian Ashill et al. (2014), Suminar \& Yulianti (2013).

\section{Pengaruh Stres Kerja Terhadap Kinerja}

Karyawan merasakan kejelasan tugas yang harus dikerjakan sehingga karyawan dapat melaksanakan pekerjaan sesuai dengan tugas yang sudah diberikan. Selain itu, karyawan memiliki hubungan yang harmonis dengan teman kerja sehingga karyawan dapat bekerjasama dengan baik untuk mencapai target yang sudah ditentukan. Tugastugas yang di berikan terselesaikan sesuai dengan waktu yang sudah ditentukan sehingga tidak ada pekerjaan yang tertumpuk dan dikerjakan keesokan harinya. Tugas yang diberikan oleh supervisor sesuai dengan kemampuan karyawan untuk menyelelsaikan dengan kuantitas dan kualitas yang sudah ditentukan. Dari beberapa kondisi diatas membuat karyawan dapat bekerja optimal sehingga berdampak pada jumlah produksi yang terus meningkat pada setiap bulannya. Hasil penelitian ini juga didukung oleh penelitian Kusuma et al. (2015).

\section{Pengaruh Konflik Pekerjaan-Keluarga Terhadap Kinerja Melalui Kelelahan Emosional}

Hasil penelitian ini menunjukkan bahwa variabel kelelahan emosional tidak dapat menjelaskan lebih baik hubungan antara konflik pekerjaan-keluarga pada kinerja karyawan PT. Morich Indo Fashion. Hasil dapat diketahui dari uji statistik yang memperlihatkan hubungan langsung konflik pekerjaan-keluarga pada kinerja lebih besar dibandingkan dengan hubungan tidak langsung konflik pekerjaan-keluarga pada kinerja melalui kelelahan emosional sebagai variabel mediasi. Karyawan yang mengalami konflik pekerjaan-keluarga mengalami kelelahan emosional karena banyaknya tanggung jawab yang harus dipenuhi oleh karyawan meskipun begitu karyawan tetap menjalankan tugasnya dengan profesional. Karyawan tetap menjalankan tugas sesuai dengan kuantitas dan kualitas yang sudah ditentukan perusahaan. Selain itu karyawan tetap masuk atau tidak terlambat untuk ke tempat kerja. Karyawan juga mampu bekerjasama dengan baik meskipun banyak permasalahan antara pekerjaan dan keluarga yang menimbulkan kelelahan emosional akan tetapi tidak mempengaruhi kinerja karyawan.

Hal tersebut menandakan karyawan mengalami konflik pekerjaan-keluarga yang disebabkan kurangnya kebersamaan keluarga dan adanya konflik antara komitmen dan tanggung jawab terhadap keluarga. Banyaknya permasalahan yang dihadapi oleh karyawan ditambah dengan tuntutan kerja dari perusahaan membuat karyawan merasa kelelahan fisik dan mental membuat karyawan kelelahan pada akhir jam kerja. Meskipun merasakan sedemikian rupa, karyawan tetap berangkat ke tempat kerja sesuai dengan jadwal dan jarang membolos kerja. Hal tersebut disebabkan karena profesionalitas pada karyawan dan rasa tanggung jawab pada pekerjaanya. Ditambah dengan kompensasi yang mencukupi, membuat karyawan menjalankan tugas dengan baik sesuai dengan target yang sudah ditetapkan. Penelitian ini juga didukung oleh Richter et al. (2015).

\section{Pengaruh Konflik Pekerjaan-Keluarga Terhadap Kinerja Melalui Stres Kerja}

Hasil penelitian ini menunjukkan bahwa stres kerja tidak dapat memediasi pengaruh konflik pekerjaan-keluarga pada kinerja. Hasil tersebut dibuktikan dengan uji statistik yang memperlihatkan bahwa nilai koefisien pengaruh langsung lebih besar dari pada pengaruh tidak langsung yaitu 0,112>0,012. Dari hasil tersebut disimpulkan bahwa 
pengaruh konflik pekerjaan-keluarga pada kinerja lebih besar dari pada pengaruh konflik pekerjaan-keluarga pada kinerja melalui stres kerja sebagai variabel mediasi.

Karyawan mengalami konflik pekerjaan-keluarga berdampak pada kondisi psikologi karyawan yang membuat karyawan mengalami stres kerja. Stres kerja yang dialami karyawan masih dalam kondisi normal artinya stres kerja yang dialami karyawan mengarah pada stres yang positif. Stres positif membuat karyawan merasa terdorong untuk berprestasi dan meningkatkan produktivitasnya sehingga kinerja karyawan semakin baik. Hasil penelitian ini didukung oleh penelitian Netemeyer et.al. (2005) yang menyatakan bahwa stres kerja tidak dapat memperkuat konflik pekerjaan-keluarga pada kinerja.

\section{KESIMPULAN DAN SARAN}

\section{Kesimpulan}

Berdasarkan hasil penelitian dan pembahasan, maka dapat disimpulkan bahwa konflik pekerjaan-keluarga berpengaruh pada kelelahan emosional artinya karyawan yang mengalami konflik antara pekerjaan-keluarga mengakibatkan karyawan mengalami kelelahan emosional. Konflik pekerjaan-keluarga berpengaruh pada stres kerja, artinya karyawan yang mengalami konflik pekerjaan-keluarga mengakibatkan karyawan stres kerja. Konflik antara pekerjaan-keluarga tidak berpengaruh pada kinerja karyawan, artinya karyawan yang mengalami konflik pekerjaan-keluarga tidak mempengaruhi kinerja karyawan karena sikap karyawan yang profesional dan bertanggung jawab pada pada pekerjaannya Kelelahan emosional tidak berpengaruh pada kinerja, artinya karyawan yang mengalami kelelahan emosional tetap bekerja sesuai dengan tugas dan tanggung jawabnya sehingga kinerja karyawan tidak menurun. Stres kerja tidak berpengaruh pada kinerja, artinya karyawan yang mengalami stres kerja tidak berdampak pada kinerja karyawan karena stres yang dialami karyawan dalam tahap sedang sehingga karyawan merasa terdorong untuk bekerja dengan baik. Tidak ada pengaruh konflik antara pekerjaan-keluarga pada kinerja melalui kelelahan emosional sebagai variabel mediasi, artinya pengaruh langsung konflik pekerjaan-keluarga pada kinerja lebih besar dari pada pengaruh tidak langsung konflik pekerjaan-keluarga pada kinerja melalui kelelahan emosional. Sehingga variabel kelelahan emosional dinyatakan dalam penelitian ini bukan variabel mediasi. Tidak ada pengaruh konflik pekerjaan-keluarga pada kinerja melalui stres kerja, artinya pengaruh langsung konflik pekerjaan-keluarga pada kinerja lebih besar dari pada pengaruh tidak langsung konflik pekerjaan-keluarga pada kinerja melalui stres kerja. Sehingga variabel stres kerja dinyatakan dalam penelitian ini bukan variabel mediasi.

\section{Saran}

Berdasarkan penelitian yang telah dilakukan oleh peneliti, maka saran yang dapat diberikan kepada pihak PT Morich Indo Fashion II dari penelitian ini, yaitu 1) Terkait dengan konflik pekerjaan-keluarga yang dialami sangat tinggi, pihak manajemen perlu memperhatikan kewajiban karyawan pada keluarga dengan cara mengatur waktu lembur sehingga karyawan tidak banyak menghabiskan waktu di tempat kerja; 2) Terkait dengan kelelahan emosional yang dirasakan karyawan, perlu di minimalisir untuk menjaga produktivitas karyawan. Pihak manajemen hendaknya membuat lingkungan kerja yang nyaman dan kondusif. Selain itu pihak manajemen diharapkan membebani tugas pada karyawan sesuai dengan kemampuan dan kondisi psikologisnya untuk mengurangi terjadinya kelelahan emosional ; 3) Terkait dengan stres kerja yang dialami karyawan, 
pihak manajemen diharapkan dapat memberikan tugas sesuai dengan kemampuan fisik dan psikologi karyawan agar karyawan tidak merasakan kelebihan tugas yang dapat berdampak pada stres kerja; 4) Terkait kinerja karyawan, perlu ditingkatkan agar targettarget yang sudah ditetapkan dapat tercapai dengan baik. Pihak manajemen perlu memberikan penghargaan bagi karyawan yang memiliki kinerja yang baik agar karyawan terpacu untuk lebih meningkatkan kinerja mereka.

\section{DAFTAR REFERENSI}

Anggriana, T. M., Wardani, S. Y., \& Margawati, T. M. (2014). Job Performance Ditinjau Dari Konflik Peran Ganda, Burnout Dan Dukungan Sosial Keluarga. Jurnal LPPM, 2(2).

Ashill, N. J., Rod, M., \& Gibbs, T. (2014). Coping With Stress: A study of retail banking service workers in Russia. Journal of Retailing and Consumer Services.

Astianto, A. (2014). Pengaruh stres kerja dan beban kerja terhadap kinerja karyawan pdam surabaya. Jurnal Ilmu \& Riset Manajemen, 3(7).

Boles, J. S., Johnston, M. W., \& Hair, J. F. (1997). Role stress, work-family conflict and emotional exhaustion: Inter_Relationships and Effects on Some Work-Related Consequences. The Journal of Personal Selling \& Sales Management, 17(1).

Christine, W. S., Oktorina, M., \& Mula, I. (2010). Pengaruh Konflik Pekerjaan dan Konflik Keluarga Terhadap Kinerja dengan Konflik Pekerjaan Keluarga Sebagai Intervening Variabel (Studi pada Dual Career Couple di Jabodetabek). Jurnal Manajemen Dan Kewirausahaan, 12(2), 121-132.

Cropanzano, R., \& Rupp, D. E. (2003). The Relationship of Emotional Exhaustion to Work Attitudes, Job Performance, and Organizational Citizenship Behaviors. Journal of Applied Psychology, 88(1), 160-169.

Cropanzano, R., Rupp, D. E., \& Byrne, Z. S. (2003). The relationship of emotional exhaustion to work attitudes, job performance, and organizational citizenship behaviors. Journal of Applied Psychology, 88(1), 160-169.

Dessler, G. (2005). Manajemen Sumber Daya Manusia (9th ed.). Jakarta: PT. Indeks Kelompok Gramedia.

Dewi, C. N. C., Bagia, I. W., \& Susila, G. P. A. J. (2014). Pengaruh Stres Kerja Dan Kepuasan Kerja Terhadap Kinerja Karyawan Pada Bagian Tenaga Penjualan UD Surya Raditya Negara. E-Journal Bisma Universitas Pendidikan Ganesha Jurusan Manajemen, 2.

Ferdinand, A. (2006). Metode Penelitian Manajemen:Pedoman Penelitian Untuk Penulisan Skripsi, Thesis, dan Disertasi Ilmu Manajemen. Semarang: Badan Penerbit Universitas Diponegoro.

Ghozali, I. (2011). Aplikasi Analisis Multivariate Dengan Program SPSS 19. Semarang: Badan Penerbit Universitas Diponegoro.

Grandey, A. A., \& Cropanzano, R. (1999). The Conservation of Resources Model Applied to Work - Family Conflict and Strain. Journal of Vocational Behavior, 54, 350-370.

Greenhaus, J. H., \& Beutell, N. J. (1985). Sources of Conflict Between Work and Family Roles. The Academy of Management Review, 10(1), 76-88.

Greenhaus, J. H., Collins, K. M., \& Shaw, J. D. (2003). The relation between workfamily balance and quality of life. Journal of Vocational Behavior, 63, 510-531.

Griffin, R. W., \& Moorhead, G. (2014). Organizational Behavior "Managing People and Organizations (17th ed.). Canada: Cengage Learning. 
Handoko. (2011). Manajemen Personalia dan Sumber Daya Manusia (2nd ed.). Yogyakarta: BPFE.

Jensen, M. T. (2014). Exploring Business Travel with Work - Family Conflict and The Emotional Exhaustion Component of Burnout as Outcome Variables: The Job Demands - Resources Perspective. European Journal of Work and Organizational Psychology, 23(4), 497-510.

Judge, T. A., \& Colquitt, J. A. (2004). Organizational Justice and Stress : The Mediating Role of Work - Family Conflict. Journal of Applied Psychology, 89(3), 395-404.

Karatepe, O. M. (2013). The effects of work overload and work-family conflict on job embeddedness and job performance: The mediation of emotional exhaustion. International Journal of Contemporary Hospitality Management, 25(4), 614-634.

Karatepe, O. M., \& Tekinkus, M. (2006). The Effects Of Work-Family Conflict, Emotional Exhaustion, And Intrinsic Motivation On Job Outcomes Of Front-Line Employees. International Journal of Bank Marketing, 24(3), 173-193.

Kreitner, R., \& Kinicki, A. (2014). Perilaku Organisasi (2nd ed.). Jakarta: Salemba Empat.

Kusuma, P. C., Raharjdo, K., \& Prasetya, A. (2015). Pengaruh Stres Kerja Dan Kualitas Kehidupan Kerja Terhadap Kepuasan Kerja dan Kinerja Karyawan (Studi pada karyawan non medis RSUD Ibnu Sina Gresik). Jurnal Administrasi Bisnis (JAB)|, $1(1), 1-9$.

Mangkunegara, A. P. (2000). Sumber Daya Manusia. Bandung: PT. Remaja Rosdayarya.

Maslach, C., \& Jackson, S. E. (1981). The Measurement of Experienced Burnout. Journal of Organizational Behavior, 2(2), 99-103.

Maslach, C., Schaufeli, W. B., \& Leiter, M. P. (2001). Job Burnout. Annu. Rev. Psychol., 52(February 2001), 397-422.

Mete, M., Faruk, Ö., \& Bilen, A. (2014). Impact of Work-Family Conflict and Burnout on Performance of Accounting Professionals. Procedia - Social and Behavioral Sciences, 131, 264-270.

Moleong, Lexy J. (2005). Metodologi Penelitian Kualitatif. Bandung: PT. Remaja Rosdakarya.

Netemeyer, R. G., Boles, J. S., \& Mcmurrian, R. (1996). Development and Validation of Work-Family Conflict and Family-Work Conflict Scales. Journal of Applied Psychology, 81(4), 400-410.

Netemeyer, R. G., Maxham, J. G., \& Pullig, C. (2005). Conflicts in the Work-Family Interface: Links to Job Stress, Customer Service Employee Performance, and Customer Purchase Intent. Journal of Marketing, 69(2), 130-143.

Panton, L. B., Kingsley, J. D., Toole, T., Cress, M. E., Abboud, G., Sirithienthad, P., McMillan, V. (2006). A comparison of physical functional performance and strength in women with fibromyalgia, age-and weight-matched controls, and older women who are healthy. Physical Therapy, 86(11), 1479-1488.

Paparang, J. P., \& Rumokoy, F. S. (2015). The Role of Internal Service Quality and Benefit Plans on Organizational Performance at Regional Drinking Water Company ( PDAM ) Sangihe. Jurnal EMBA, 3(3), 109-117.

Poernomo, U. D., \& Wulansari, N. A. (2015a). Pengaruh Konflik pekerjaan keluarga pada Kinerja Karyawan dengan Kelelahan Emosional sebagai Variabel Pemediasi. Management Analysis Journal, 4(3), 190-199.

Poernomo, U. D., \& Wulansari, N. A. (2015b). Pengaruh Konflik pekerjaan keluarga Pada Kinerja Karyawan Dengan Kelelahan Emosional Sebagai Variabel Pemediasi. Management Analysis Journal, 4(3), 190-199. 
Prel, J.-B. du, \& Peter, R. (2015). Work-family conflict as a mediator in the association between work stress and depressive symptoms : cross - sectional evidence from the German lidA - cohort study. Int Arch Occup Environ Health, 88, 359-368.

Rajak, A. (2013). Pengaruh Konflik Interpersonal, Work-Family Conflict dan Stres, terhadap Kepuasan Kerja dan Dampaknya terhadap Kepuasan Hidup. Journal Siasat Bisnis, 17(2), 131-156.

Ranihusna, D., \& Wulansari, N. A. (2015). Reducing The Role Conflict of Working Woman: Between Work and Family Centrality. Jurnal Dinamika Manajemen, 6(2), 214-225.

Richter, A., Schraml, K., \& Leineweber, C. (2015). Work-family conflict, emotional exhaustion and performance-based self-esteem: reciprocal relationships. International Archives of Occupational and Environmental Health, 88(1), 103-112.

Robbins, S. P., \& Judge, T. A. (2008). Perilaku Organisasi (12th ed.). Jakarta: Salemba Empat.

Rubioa, C., Osca, A., Recio, P., Urien, B., \& Peiró, J. M. (2015). Work-Family Conflict, Self-Efficacy, And Emotional Exhaustion: A Test Of Longitudinal Effects. Journal Of Work And Organizational Psychology, 31, 147-154.

Sarwono, J. (2007). Analisis Jalur untuk Riset Bisnis dengan SPSS. Yogyakarta: CV. ANDI.

Setyono, A., Rahardjo, M., Nugraheni, R., \& Rahardja, E. (2007). Analisis Faktor-Faktor Yang Mempengaruhi Kerja Dan Kinerja Salesman ( Studi Kasus Pada Pt . Adira Finance Cabang Bangkong Semarang ). Jurnal Studi Manajemen \& OrganisasI, 4(2), 70-80.

Sukmawati, Thoyib, A., \& Surachman. (2013). Peran Organizational Citizenship Behavior sebagai Mediator Pengaruh Kepuasan Kerja , Lingkungan Kerja dan Komitmen Organisasi terhadap. Aplikasi Manajemen, 11(4), 547-558.

Suminar, B., \& Yulianti, E. (2013). The Effect of Emotional Exhaustion on Job Satisfaction and its Impact on Performance. International Peer Reviewed Journal, $5,162-174$.

Tarwaka. (2013). Ergonomi Industri Dasar-Dasar Pengetahuan Ergonomi dan Aplikasi di Tempat Kerja. Surakarta: Harapan Press.

Tziner, A., \& Sharoni, G. (2014). Organizational citizenship behavior, organizational justice, job stress, and work- family conflict: Examination of their interrelationships with respondents from a non-Western culture. Journal of Work and Organizational Psychology, 30, 35-42.

Wallace, J. E. (2005). Job Stress, Depression and Work-to-Family Conflict: A Test of the Strain and Buffer Hypotheses. Relations Industrielles, 60(3).

Warokka, A., \& Febrilia, I. (2015a). Work-Family Conflict and Job Performance: Lesson from a Southeast Asian Emerging Market. Journal of Southeast Asian Research.

Warokka, A., \& Febrilia, I. (2015b). Work-family conflict and job performance: Lesson from a Southeast Asian emerging market. Journal of Southeast Asian Research, 114.

Wisantyo, \& Madiistriyatno. (2015). Pengaruh Stres Kerja, Disiplin Kerja Dan Kepuasan Kerja Terhadap Intensi Turnover (Studi padaLembagaPengelola Dana Bergulir Koperasi danUsaha Mikro, Kecil dan Menengah ). Jurnal MIX, 5(1), 54-69. 